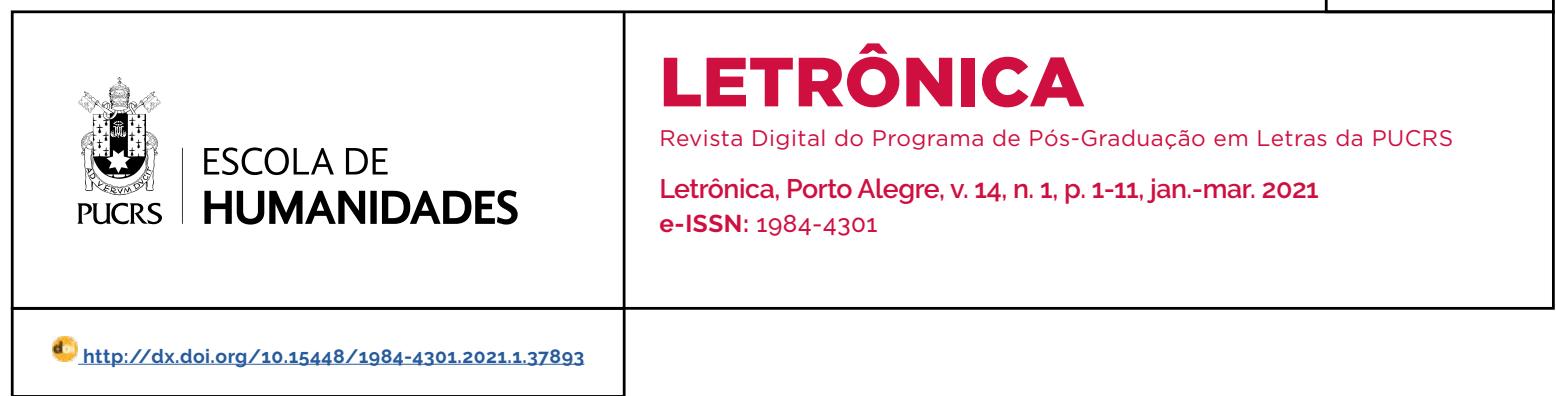

ARTIGO

\title{
Espaços urbanos em trânsito na poesia de Antonio Cicero
}

\author{
Urban spaces in traffic in Antonio Cicero poetry \\ Espacios urbanos em tránsito em la poesía de Antonio Cicero
}

\section{Paulo Alberto da Silva Sales $^{1}$}

orcid.org/0000-0001-9980-2561 paulo.alberto@ifgoiano.edu.br

Recebido em: 30/4/2020. Aprovado em: 6/8/2020. Publicamo em: $9 / 6 / 2021$.

\section{(c) (i)}

Artigo está licenciado sob forma de uma licença Creative Commons Atribuição 4.0 Internacional.
Resumo: A poesia brasileira contemporânea, sobretudo aquela produzida desde a década de 1980, tem apresentado relações diretas entre as paisagens citadinas e a subjetividade. Em poéticas assumidamente espaciais, o sujeito lírico é confrontado com novas experiências urbanas que ampliaram sua percepção de mundo na observância dos gestos que marcam o cotidiano. Nessas revelações, a poesia passa a investir na primeira pessoa endereçada, ao promover a expansão da noção de sujeito lírico que, por sua vez, passa a se identificar com espaços e imagens visuais. Essas associações criam um sujeito fora de si que, por meio de seu contato com diferentes lugares, cria uma nova experiência do olhar que rompe com as fronteiras dentro/fora. Partindo da expansividade e o endereçamento poético aos diversos espaços urbanos, apresentamos uma leitura de alguns poemas presentes nos livros A cidade e os livros (2002) e Porventura (2012), do poeta Antonio Cicero. Nessas obras, as experiências do tema urbano aparecem em poemas que evidenciam a relação poesia e paisagem e como essa relação, no poeta em questão, marca a imprecisão tempo-espacial da cidade contemporânea ao mesclar as paisagens da urbe a espaços e a tempos míticos. Palavras-chave: Poesia brasileira contemporânea. Espaços urbanos. Antonio Cicero.

Abstract: The Brazilian contemporary poetry mainly that produced since 1980 has presented direct relations between city sights and subjectivity. In assumed space poetics the lyrical subject is faced with new city experiences that expand its world perception in observation of daily gestures. In these revelations the poetry takes to the investment in the first person who is addressed and it promotes the expansion of lyrical subject notion that by its time identifies itself with spaces and visual images. These associations create an out of mind subject who identifies itself to the different urban spaces. In this interaction, the lyrical subject creates a new look experience that breaks up the in/out. From the expansiveness and poetic addressed in many urban spaces, we analyze some poems of the books A cidade e os livros (2002) and Porventura (2012), by the poet Antonio Cicero. In these works, the urban theme present at the poems reflects the poetry and landscape relationship and with this and by the Brazilian poet's work, his poems are marked by space and time imprecision of contemporary city that mixtures to the mythical times and spaces. Keywords: Brazilian contemporary poetry. Urban spaces. Antonio Cicero.

Resumen: La poesia brasileña contemporánea, especialmente la producida desde la década de 1980, ha mostrado relaciones directas entre paisajes de ciudad y subjetividad. En poéticas admitidas como espaciales, el sujeto lírico se enfrenta a nuevas experiencias de la ciudad que ampliaron supercepción de mundo em la observación de los gestos que marcan la vida cotidiana. En estas revelaciones, la poesia comienza a invertiren la primera persona dirigida, que promueve la expansión de la noción de sujeto lírico que, a su vez, empieza a identificarse com espacios e imágenes visuales. Estas asociaciones creanun sujeto fuera de simismo y quien, al tener contacto con diferentes espacios urbanos, crea una nueva experiencia de la mirada que rompe los límites dentro/fuera a través de imágenes visuales que se mezclan con fragmentos de memoria poética. Tomando como guia la perspectiva de la expansividad y el direccionamiento poético a los diversos espacios urbanos, presentamos una lectura de algunos poemas presentes em los libros $A$ 
Cidade e os Livros (2002) y Porventura (2012), del poeta Antonio Cicero. Se busca configurar las experiencias del tema urbano en poemas que desarrollan una reflexión acerca de la relación entre poesía y paisaje y como esta relación, em el poeta em cuestión, está marcada por la imprecisión espacio-temporal.

Palabras clave: Poesia brasileña contemporánea. Espacios Urbanos. Antonio Cicero.

\section{Poesia e espaços urbanos}

Ao se referir ao livro o problema da habitação (1962), do poeta português Ruy Belo, Ida Alves (2015) traz à baila a discussão sobre a relação desarmônica entre homem e tempo-espaço citadino. Os sentimentos de estar sempre "fora do lugar" e de não se identificar com as paisagens ao seu redor fizeram com que aquele poeta lusitano afirmasse: "não há tempo ou lugar onde habitar". Para Alves, a palavra poética em Ruy Belo, bem como em vários outros poetas de sua geração, consolida-se por meio da representação desajustada de indivíduos que não se veem pertencentes às novas paisagens que os cercam, moldadas, sobretudo, por prédios, concretos e por labirintos intermináveis que se desembocam em avenidas, ruas e vielas.

O anseio de indivíduos pela contemplação de espaços confortantes, sejam eles naturais ou de outra ordem, impulsionaram poéticas do último quartel do século XX e início do século XXI, tanto portuguesas quanto brasileiras, a investirem no tratamento do tema urbano, o que levou alguns teóricos a se debruçarem sobre tal questão. Um dos principais nomes é Michel Collot (1997, 2011, 2012), para o qual a questão da paisagem se investe de inúmeras significações que estão ligadas à existência e ao inconsciente do sujeito que a experimenta. Por meio dessa inter-relação, o recente gesto lírico ocupou-se de tratar da conflituosa relação entre subjetividade e paisagem, por meio do que Alves identificou como "força semântica da perda", a partir dos deslocamentos de indivíduos pelos diferentes espaços urbanos. Sob esse prisma, a desterritorialização do sujeito ${ }^{2}$ passou a ser registrada no texto poético sob o ponto de vista geográfico e também pelo viés humano: "É com o signo da negatividade, da falta, de 'ocupações provisórias' que a cidade tem se materializado na poesia contemporânea" (ALVES, 2015, p. 7).

No caso específico da poesia brasileira, a presença do universo citadino é tratada na lírica com mais proficuidade desde o romantismo, muito embora em poemas como os de Álvares de Azevedo, por exemplo, as paisagens fossem expressas de forma etérea - por meio da representação de devaneios nos quais se vislumbravam imagens de praias, do mar, de montanhas e de campos - e também de forma degradada, referindo-se à cemitérios e outros lugares lúgubres. Nesses espaços, o cenário urbano aparecia como uma extensão da subjetividade do poeta e havia um elo harmônico entre o estado de espírito para com as paisagens. Mas seria tão somente no modernismo que as paisagens da urbe iriam ter maior visibilidade e começariam a indicar desajustes entre homem e espaço. A vida dos sujeitos da cidade de São Paulo, metrópole cultural dos primeiros decênios do século $X X$, aparecia em meio à efervescência das inovações e dos aparatos da modernidade, carregada de certos "desvairismos" e de uma dicção irônica e crítica.

Poetas como Mário de Andrade, em sua Pauliceia desvairada, publicada em1922,3 bem como Oswald de Andrade, em Poesia Pau Brasil, de 1925, já registravam a confluência de paisagens naturais às da cidade que eram expressas simultaneamente por meio de uma dicção atropelada, que pregava a velocidade, qualidade, essa, tão cara à vanguarda futurista. Referências a rios, parques, prédios, casas, monumentos, museus, caminhões, carros, carroças, avenidas e ruas marcam a expansão do sentir lírico: "Os caminhões rodando, as carroças rodando,/ Rápidas as ruas se desenrolando,/ Rumor surdo e rouco, estrépitos, estalidos.../E o largo coro de ouro das sacas de café!..." (ANDRADE, 1987, p. 102). Nessa primeira estrofe do poema "paisagem n ${ }^{\circ} 4$ ", a configuração

\footnotetext{
Portamo-nos aqui ao sentido empregado por Gilles Deleuze e Félix Guattari (2010) em Anti-Édipo: capitalismo e esquizofrenia

A esse respeito, ver as configurações que Mário de Andrade constrói da multifacetada cidade de São Paulo, a partir da leitura de alguns poemas emblemáticos, tais como "A inspiração", "Rua de São Bento", "Tietê", "Anhangabaú", "Paisagem n 1", "Paisagem n² 2", "Pai-

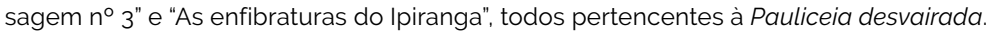


do espaço urbano acompanha a velocidade da modernidade, e a subjetividade, desde então, começava a encontrar-se "fora de si" (COLLOT, 2013). Tais desencontros e desarmonias entre o ambiente externo e a interioridade levaria outros poetas modernistas a investirem em percepções imagéticas carregadas de forte subjetividade urbana, tais como nas poéticas de Manuel Bandeira e de Carlos Drummond de Andrade, por tratarem não só de paisagens dos grandes centros, mas, em especial, por apresentarem outras cidades ("Itabira", "Recife", "Capibaribi", "Petrópolis" ou mesmo a longínqua "Pasárgada") pouco grafadas, até então, pela poesia brasileira. Na contemporaneidade, seria ainda mais sintomático a presença de temas urbanos e de espaços em trânsito, mais detidamente a partir das décadas de 1980 e 1990, materializando-se em poetas que trazem a espacialidade urbana desajustada às experiências do sujeito lírico que se movimenta pelos grandes centros, tais como na já citada São Paulo e no Rio de Janeiro. A nosso ver, merecem destaque os poetas Fabiano Calixto (1973 -), do Pernambuco4; Arnaldo Antunes (1960 -) e Marcos Siscar (1964 -), ambos paulistas; Ana Cristina César (1952 - 1983), Carlito Azevedo5 (1961 -) e Antonio Cicero (1945 -), todos os três cariocas. Será por meio da leitura de alguns poemas desse último poeta fluminense - pertencentes às obras As cidades e os livros, de 2002, e Porventura, de 2012 -, que nos deteremos aqui.

\section{Poesia e cidade em Antonio Cicero}

Poeta e filósofo de formação, além de letrista de música popular, ${ }^{6}$ Antonio Cicero publicou os livros de crítica e pensamento filosófico O mundo desde o fim (1995), Finalidades sem fim (2005), Poesia e filosofia (2012) e A poesia e a crítica (2017). É autor dos livros de poesia Guardar (1996) e das duas obras com as quais nos deteremos, As cidades e os livros (2002) e Porventura (2012). Nesses dois últimos livros de poesia, nota-se uma dicção poética que promove encontros de tempos e de espaços díspares, fundindo-os todos em múltiplas paisagens citadinas do Rio de Janeiro. Nos trinta e quatro poemas que compõem a obra As cidades e os livros, observa-se forte carga imagética de elementos urbanos modernos, contemporâneos e de outros tempos passados, sobretudo, ligados ao universo grego. A problematização do espaço urbano é destacada desde a capa do livro: nela, o poeta apropria-se de elementos artísticos do pintor suiço Paul Klee (1879 - 1940), um dos principais nomes do modernismo europeu. Suas telas rompiam com as representações imagéticas realistas, ao propor a desestruturação das formas e dos espaços a partir da mescla de elementos cubistas, surrealistas e expressionistas. A frase "a arte não reproduz o visivel: ela torna visivel" é de sua autoria e, não à toa, aplica-se perfeitamente à proposta de $A$ cidade e os livros. A projeção de espaços incertos e translúcidos presentes na capa da obra - feitos a partir de construções irregulares em cubos e em retângulos - funciona como um convite à desestruturação e ao deslocamento dos espaços, tendo em vista que eles, vistos somente pelo ângulo da realidade, não são suficientemente capazes de exprimir os sentimentos do sujeito lírico. Confirma, também, essa proposta de desapropriação espacial, a epígrafe que abre o livro. Trata-se do poema "Espaço", da poeta judaica Rose Ausländer (1901 - 1988), cujos tumultuados percalços presentes em sua vida, devido à sensação de não pertencimento a certos contextos da URSS, visualizam-se em sua escrita poética: "Ainda há espaço/ para um poema/ Ainda é o poema/ um espaço/ Onde se pode/ respirar?" (CICERO, 2002, p. 7).

\footnotetext{
4 Embora tenha nascido em Garanhuns, Fabiano Calixto mudou-se para a cidade de São Paulo, lugar onde fez seus estudos e no qual consolidou o tema urbano como mote de sua escrita poética. Em grande parte dos seus poemas, o tratamento da paisagem urbana é feito a partir da descrição dos aspectos físicos e pelo registro da solidão de personagens anônimas que transitam pela maior cidade brasileira. 5 No que se refere à relação entre poesia e paisagem, bem como dos hibridismos típicos de poéticas da contemporaneidade, ver a obra Sublunar, obra, essa, que condensa poemas pertencentes às publicações anteriores que foram reunidos nesta antologia a partir de sessões temáticas.

6 Autor de poemas-canções e letras de músicas compostas em parceria, inicialmente, com sua irmã, a cantora Marina Lima.

7 Antes da tradução para a língua portuguesa, o poema é citado por Antonio Cicero em lingua alemã: "NochistRaum/füreinGedicht/ Nochist das Gedicht/ einRaum/ Womanatmenkann".
} 
Mesmo em alguns poemas nos quais se constata uma subjetividade homoerótica, há, também neles, a mescla de elementos espaciais diversos que remetem a temporalidades do passado que são problematizados na escrita poética contemporânea. Em todos os outros, os temas urbanos são diversos e o sujeito projeta sua experiência do olhar por meio das paisagens, tais como praias, morros, rios, avenidas, esquinas, becos, lojas, comércios populares, monumentos e construções arquitetônicas. Tais espaços, muitos deles amplamente conhecidos - sejam eles naturais ou construções humanas - tornam-se atemporais e movediços. Os poemas "Museu de arte contemporânea" e "Ônibus" são exemplares para se visualizar a transitoriedade das percepções de espaços urbanos. A configuração de paisagens citadinas é amplamente carregada pela subjetividade do olhar de sujeitos que saem de si para se encontrarem em tais espaços, redimensionando-os. Neles, lemos:

\section{Museu de Arte Contemporânea}

Fica em Boa Viagem. Disco voador ele não é, pois não pousou na pedra mas se ergue sobre ela; nem alça voo: à orla de cidades e florestas suspende-se no ar feito pergunta e o que tem dentro mergulha e se banha no mundo em volta e o mundo em volta o inunda: é o museu fora de si, de atalaia à curva do abismo, à altura das musas, sobre o mar, sobre a pedra sobre o mar, e sobre o espelho d'água em que se apura sobre essa pedra um mar a flutuar, um céu na terra, quase nada, um aire, a flor de concreto do Niemeyer. (CICERO, 2002, p. 15)

Ônibus

Para Eucanaã Ferraz

São oito horas da noite, véspera da véspera de outro Natal. Já não há lâmpadas feéricas vindas da China a iluminar as ruas. O racionamento as eliminou. Um só ônibus dá-se a tal luxo e vai acesso, vestido de lâmpadas, pródigo
da luz que the enquadra as janelas por onde à contraluz se enxergam os seus sombrios passageiros voltando mortos para casa: longa meândrica jornada através de um obscuro espelho (CICERO, 2002, p. 61).

A experiência do olhar presente na descrição do Museu de Arte Contemporânea no mirante da Boa Viagem, situado à orla da cidade de Niterói e banhado pelas águas da Baía de Guanabara, desloca-o espacialmente, no segundo e terceiro versos, para outra dimensão, o que faz com que sua construção física passe a estar "fora de si". Em seguida, o sujeito poético o associa à forma de um disco voador, que sai de sua localização tempo-espacial e vai de encontro à cosmologia pagã: "à orla de cidades e florestas/ suspende-se no ar feito pergunta/ e o que tem dentro mergulha e se banha/ no mundo em volta e o mundo em volta o inunda". A paisagem física desmaterializa-se e torna-se uma extensão indagativa do sujeito que o observa. Percepções em trânsito também se instauram na observação que o sujeito lírico faz de um meio de transporte em um contexto de festividade na cidade. A véspera do Natal, a voz lírica identifica-se com as vivências observadas que vão além da descrição de efemeridades cotidianas e das contingências sofridas pelos cidadãos (Já não há lâmpadas feéricas/vindas da China a iluminar/as ruas. 0 racionamento/ as eliminou). A existência ínfima dos sujeitos citadinos também é percebida por um sujeito lírico ensimesmado que, por meio do contato com a realidade alheia, vê-se através de um "obscuro espelho" (Os seus sombrios passageiros/voltando mortos para casa). Nota-se, em ambos os poemas, a descrição de cenas presentes em dias comuns que levam o sujeito lírico a identificar-se com o objeto externo, abrindo-se para o mundo e para o outro. Essa abertura para o mundo aparece de forma explícita no poema "Merde de poète", no qual o eu lírico ridiculariza a concepção de poesia romântica como estado de espirito: "Quem gosta de poesia visceral/ ou seja, porca, preguiçosa, lerda/ que vá ao fundo e seja 
literal,/ pedindo ao poeta, em vez de poemas, merda" (CICERO, 2002, p. 21). O poema evidencia o trabalho poético como sendo uma construção do pensamento a partir da sua relação com o mundo. Ao sair de si, o sujeito coincide consigo mesmo, não como uma construção identitária rígida, mas como quer Collot (2013), por meio ipseidade que não exclui o outro, mas sim o inclui. Logo, é vital para o entendimento da poesia de Antonio Cicero entender que "o sujeito lírico, liberto de seu querer individual, tem acesso à objetividade; ele se torna uma espécie de médium através do qual se exprime o único sujeito verdadeiramente existente, que não é senão o artista original do universo" (COLLOT, 2013, p. 224).

A palavra poética articula o sentimento de não pertencimento do sujeito poético a espaços urbanos pelos quais ele transita, fazendo-o expressar, simultaneamente, certa perplexidade -"Não sei bem onde foi que me perdi; talvez nem tenha me perdido mesmo,/ mas como é estranho pensar que isto aqui/ fosse meu destino desde o começo" (CICERO, 2002, p .67) - e descontentamento frente à realidade paisagística: "la ao centro da cidade/e me achava em livrarias,/ livros, páginas, Bagdad,/ Londres, Rio, Alexandradia:/ Que cidade foi aquela/ em que me sonhei perder/ e antes disso acontecer/ aconteceu-me perdê-la?" (CICERO, 2002, p. 75).

Dando continuidade ao tratamento do tema urbano, o livro Porventura (2012), composto por trinta e cinco poemas, articula a percepção de sujeitos que problematizam o seu estar-no-mundo a partir do enfrentamento das paisagens urbanas do Rio de Janeiro.

A escolha do próprio advérbio que intitula a obra induz o leitor à semântica das representações de espaços moldados por "situações hipotéticas", por "possibilidades", pela criação de "acontecimentos", por formas em "devir" e por criações que podem "vir a ser". A "porventura" esmaece a fixidez dos espaços da cidade, que, por sua vez, passam a ser tornar nulos e são descritos como pura potência. Em muitos casos, tais locais não identificados no cenário urbano se acabam transformando em topos da reflexão poética do tempo presente, tal como se percebe nos poemas "As flores da cidade" e "presente":
As flores da cidade

Há flores pelo caminho através da cidade à cidade: naturais, em canteiros e em árvores, talvez, mas quase todas artificiais nos cabelos dos bebês, em cachorros mimados, em vitrines e revistas femininas, em cartazes e outdoors, e - de novo naturais - em floristas, camelôs na calçada e, sobretudo, nas mãos do entregador de flores, cujo olhar esverdeado sobre as rosas é puro absinto e tudo nos deslembra lançando-nos dúvidas hiperbólicas sobre o próprio destino a uma hora dessas. (CICERO, 2012, p. 71)

\section{Presente \\ Para Eucanaã Ferraz}

Porque não se deitar sobre este gramado, se o consente o tempo, e há um cheiro de flores e verde e um céu azul por firmamento e a brisa displicentemente acaricia-me os cabelos? E por que não, por um momento, nem me lembrar que há sofrimento, de um lado e de outro e atrás e a frente e, ouvindo os pássaros ao vento sem mais nem menos, de repente, antes que a idade breve leve cabelos sonhos devaneios, dar a mim mesmo este presente? (CICERO, 2012, p. 39).

O olhar atento às efemeridades e às artificialidades presentes nos gestos de sujeitos anônimos, entre flores artificiais e naturais do cotidiano, toca o sujeito que se vê em abismos e em situações deslocadas. O próprio ato de caminhar pelas ruas dos grandes centros urbanos aparece, segundo o Indicionário do contemporâneo, de Célia Pedrosa et al. (2018, p. 125), como leitmotiv da experiência de contemporaneidade da arte, que foi contemplada de forma emblemática, primeiramente, na poesia de Charles Baudelaire. Em meio à diversidade de pessoas e ao trânsito turbulento da cidade moderna, a poesia começou a impregnar-se de experiências que enlamearam a aura do poeta. Por meio de trocas de experiências com 
o meio urbano, o campo da lírica foi ampliado, e enriqueceu-se ao agregar elementos da cotidianidade urbana. Outros dois poemas da obra Porventura possibilitam visualizar subjetividades projetadas em espaços em trânsito:

Meio-fio

Domingo à noite, ao cinema,

à comédia americana

do Roxy, em Copacabana:

que melhor estratagema

para vencer a acedia

domingueira, num programa -

sonorama, cinerama -

com um toque de nostalgia,

drops e ar condicionado,

e um trailer, de aperitivo

(que filme é mais incisivo

que o somente insinuado?)

Mas, na Barão de Ipanema

Com a Domingos Ferreira,

eis que fazemos besteira,

a um quarteirão do cinema:

è que, à procura de vaga,

não vemos que vem um carro

na transversal, e o esbarro

não é grande mas estraga

os planos. Resta esperar

ao meio-fio a perícia.

Mas a noite, com a malícia

e a fluidez de um jaguar,

nada espera. Da Avenida

Atlântica, a maresia

cio marinho, alicia

para outras eras da vida

(CICERO, 2012, p. 37).

\section{Blackout}

Passo a noite a escrever.

Do lado de lá da rua

poderia alguém me ver,

daquele prédio às escuras,

em frente ao meu, e mais alto.

Que voyeur me espiaria?

De interessante, só faço

escrever: Ele veria

decerto a parte traseira

do computador; talvez,

daquela outra janela,

avistasse, de viés,

o lado esquerdo da minha

\author{
face de perfil; jamais \\ entretanto enxergaria \\ certos versos de cristal \\ liquido que, mal secreto \\ com o sal do meu suor, \\ já anunciam segredos \\ só meus e de algum leitor \\ que partilhará comigo \\ o paraiso e o desterro, \\ o pranto que vem do riso, \\ o acerto que vem do erro. \\ Disso tudo, meu vizinho \\ nem de longe desconfia. \\ Mas e se ele, tendo lido \\ meus lábios, que pronunciam \\ o que na tela está escrito, \\ percebe-se desterrado \\ não só do meu paraíso: \\ do meu desterro, coitado? \\ E se ele a tudo atentar \\ e por inveja e recalque \\ me der um tiro de lá? \\ Melhor fechar o blackout \\ (CICERO, 2012, p. 47-48).
}

As eventualidades flagradas nos poemas detêm-se a espaços noturnos da cidade maravilhosa que reverberam sensações no sujeito, que, por meio do contato com tais paisagens, experencia as "besteiras" acometidas "...na Barão de Ipanema/ Com a Domingos Ferreira". Entre prédios e ruas, também, há um sujeito a escrever poesia atrás de suas cortinas em blackout, o que lhe daria certa privacidade em meio aos voyeurs que, possivelmente, o espiariam. Os incômodos provocados pelo contato dos sujeitos com as paisagens levam-no para além do problema espacial momentâneo. O presente torna-se atemporal, ao passo que pode ser engendrado a outras temporalidades passadas no momento presente, tornando-o anacrônico.

As experiências da visualidade e dos espaços da cidade em A cidade e os livros e Porventura aparecem de forma mais radicalizada nos embates existenciais de indivíduos ao se depararem com novas experiências de espaço e tempo. Para Ida Alves (2010), o sujeito lírico que está configurado nesse tipo de poesia tem, na sua visão, o seu mais agudo sentido de percepção do mundo, ao observar os gestos citadinos que marcam o coti- 
diano e revelam suas pequenas histórias diárias. A relação do sujeito com os espaços é expressada por sintomas de uma relação desconcertante, que é consolidada por meio da palavra poética. Nesse impasse da subjetividade que não se harmoniza com os espaços, "experiencia-se o estranhamento e o desencontro frente à realidade das cidades transformadas velozmente, com consequentes e fundas perdas de memória espacial e afetiva para o sujeito que as vivencia" (ALVES, 2010, p. 207). Por meio da leitura dos poemas "As cidades e os livros", título homônimo ao da obra de 2002, e "Cidade", de Porventura, nota-se a dissolução de quaisquer contingencialidades temporais, locais e particulares do sujeito contemporâneo ao se ver em uma dimensão indeterminada, atemporal e anônima:

A cidade e os livros

O Rio parecia inesgotável

àquele adolescente que era eu.

Sozinho entrar no ônibus Castelo,

saltar no fim da linha, andar sem medo

no centro da cidade proibida,

em meio à multidão que nem notava

que eu não the pertencia - e de repente,

anônimo entre anônimos, notar

eufórico que sim, que pertencia

a ela, e ela a mim -, entrar em becos,

travessias, avenidas, galerias,

cinemas, Livrarias: Leonardo

da Vinci Larga Rex Central Colombo

Marrecas Íris Meio-Dia Cosmos

Marrocos Passos Civilização

Cavé Saara São José Rosário

Passeio Público Ouvidor Padrão

Vitória Lavradio Cinelândia:

lugares que antes eu nem conhecia

abriam-se em esquinas infinitas

de ruas doravante prolongáveis

por todas as cidades que existiam.

Eu só sentia algo semelhante

ao perceber que os livros dos adultos

também me interessavam: que em principio

haviam sido escritos para mim

os livros todos. Hoje é diferente,

pois todas as coisas encolheram.

são previsiveis, dão claustrofobia

e até dariam tédio, se não fossem

os livros infinitos que contêm

(CICERO, 2002, p. 19-20).

\author{
Cidade \\ Lembro que o futuro era uma cidade \\ nebulosa da qual eu esperava \\ tudo e que, sendo uma cidade, nada \\ esperava de ninguém. Ah, a cidade \\ sonhada de avenidas macadâmicas, \\ turbas febris e prédios de granito: \\ o que era que eu perdera e que, perdido \\ e em cacos, buscava nas tuas áridas \\ calçadas e esquinas? Hoje constato \\ que a névoa do futuro do passado \\ adensa-se dia a dia. De longe, \\ teus contornos são mais arredondados. \\ Tu, cidade irreal, aos poucos somes: \\ já anseio te rever e já te escondes \\ (CICERO, 2012, p. 65).
}

A carga imagética citadina presente nos versos observadas por um sujeito a caminhar pela "cidade inesgotável", "proibida" e "que nem notava" evoca emoções distintas no sujeito poético em diferentes momentos de sua vida. O até então adolescente está a transitar de um lugar ao outro e passa por "becos,/ travessas, avenidas, galerias, / cinemas, Livrarias: Leonardo/ da Vinci Larga Rex Central Colombo/ Marrecas Íris Meio-Dia Cosmos/Alfândega Cruzeiro Carioca/ Marrocos Passos Civilização/ Cavé Saara São José Rosário/ Passeio Público Ouvidor Padrão/Vitória Lavradio Cinelândia". A descrição feita de tais espaços, sem recorrer ao uso da pontuação, faz com que o sujeito poético se encontre fora de si e deixe de lado suas individualidades. No embate com a multidão, o eu lírico experimenta a alteridade e reconhece "que pertencia a ela, e ela a mim", passando, então, "anônimo entre anônimos" a compartilhar as incertezas uns dos outros. Fortemente marcado por aspectos memorialísticos, nos quais se encontram passado, presente e futuro, ao que tudo indica, o contato com diferentes paisagens urbanas tem, em um primeiro momento, o deslumbramento de sujeitos que se viam pertencentes à urbe. Entretanto, no contato com as "turbas febris e prédios de granito:/o que era que eu perdera e que, perdido/e em cacos, buscava nas tuas áridas/calçadas e esquinas?", o estar-no-mundo contemporâneo dessa "cidade irreal, aos poucos somes"/ já anseio te rever e já te escondes" e 
tornou-se desoladora: " Hoje é diferente,/ pois todas as coisas encolheram,/ são previsiveis, dão claustrofobia/ e até dariam tédio, se não fossem/ os livros infinitos que contêm." O enfrentamento dessas paisagens desestrutura o sujeito lírico que passa, então, a rememorar imagens dessa mesma cidade em momentos pretéritos:

Antigo verão

Primeiro a praia, depois uma estreia, depois o Baixo, e finalmente a festa de madrugada, uma cobertura: e eis que as nuvens a cobrir a lua e o Corcovado já se dispersavam, auspiciando uma manhã de praia para um rapaz que àquela altura era o derradeiro barco pra Citera (CICERO, 2002, p. 31).

O embate com a realidade citadina torna-se angustiante. Por essa razão, vários poemas de As cidades e os livros e de Porventura voltam-se a contextos, tempos e espaços da mitologia grega. Divindades gregas são inseridas em dimensões nitidamente contemporâneas - dimensões, essas, que são reconhecidas por meio das descrições que o poeta faz dos espaços citadinos de hoje -, muito embora não se perceba uma demarcação temporal que as separe. Nomes do universo helênico como Proteu, İcaro, Dédalo, Fédra, Ájax, Perseu, Medusa e outras tantas personalidades vivem experiências únicas nos entraves com a paisagem urbana contemporânea. A esse respeito, os poemas "O grito" e "Vitrine", ambos de As cidades e os livros, trazem os impasses dos mitos de Prometeu e de Narciso associados às angústias da sociedade do consumo do início do século XXI:

Orito

Estou acorrentado a este penhasco logo eu que roubei o fogo dos céus. Há muito tempo sei que este penhasco não existe, como tampouco há um deus a me punir, mas sigo acorrentado. Aguardam-me amplos caminhos no mar e urbes formigantes a engendrar cruzamentos febris e inopinadas. Artur diz "claro" e recomenda um amigo que parcela pacotes de excursões. Abutres devoram-me as decisões e uma ponta do fígado mas digo: E daí? Dia desses com um só grito eu estraçalho todos os grilhões (CICERO, 2002, p. 33).

Vitrine

Que divisa o olhar desse moreno? Namora o tênis atrás da vitrine? Ou a vidraça que os devassa e inibe os seus reflexos serve-lhe de espelho e ele recai na imagem de si mesmo, igualmente visivel e intangivel? É assim tantálica que ela me atinge obliquamente e ao mesmo tempo em cheio e mesmeriza, e sinto meio como se eu o despisse e ele mal percebesse. Quando olha para trás um instante, atino sonhar e, salvo engano, ter nos olhos cacos de um campo de futebol verde feito o pano das mesas dos cassinos (CICERO, 2002, p. 55).

O imbricamento de mitos gregos aos contextos pós-modernos torna a contemplação da paisagem atemporal. Na poesia de Antonio Cicero, tais procedimentos poéticos aparecem desde a sua primeira obra, Guardar, de 1996. Pela investida às explicações míticas de verdades como revelação, além da noção de tempo como temporalidade divina e da noção mítica de mundo como um conjunto único e múltiplo de teofanias convergidas aos acontecimentos do mundo contemporâneo, pode-se fazer, de certa maneira, uma releitura dos fundamentos da Teogonia, de Hesiodo (2011), na era contemporânea. As paisagens, mesmo remetendo a espaços conhecidos da cidade do Rio de Janeiro, experimentam a noção mítica da linguagem como uma manifestação divina por intermédio das deusas musas, filhas de Zeus, e de Mnemosyne, que constituem o fundamento dos cantos. Isso não significa que Antonio Cicero faz uma ponte direta que liga sua poética ao tempo da origem dos deuses como mero artifício intertextual, mas, sim, pela apropriação de um sentimento de exultação nostálgica que resulta em uma eclosão intempestiva de um estar fora do tempo. Contrapondo tais perspectivas, obser- 
ve-se, de forma comparativa, o trecho inicial da Teogonia, especificamente a parte do proêmio na qual há o hino às musas, com os poemas "Prólogo", que abre As cidades e os livros, e "O poeta lírico", de Porventura:

\section{[...]}

Pelas musas e pelo golpeante Apolo há cantores e citaristas sobre a terra, e por Zeus, reis. Feliz é quem as Musas amam, doce de sua boca flui a voz. Se com angústia no ânimo recém-ferido alguém aflito mirra o coração e se o cantor servo das Musas hineia a glória dos antigos e os venturosos Deuses que têm o Olimpo, logo esquece os pesares e de nenhuma aflição se lembra, já os desviaram os dons das Deusas. Alegrai, filhas de Zeus, dai ardente canto, gloriai o sagrado ser dos imortais sempre vivos, os que nasceram da Terra e do Céu constelado, os da Noite trevosa, os que o salgado Mar criou. Dizei como no começo Deuses e Terra nasceram, os Rios, o Mar infinito impetuoso de ondas, os Astros brilhantes e o Céu amplo em cima. Os deles nascidos Deuses doadores de bens como dividiram a opulência e repartiram as honras e como no começo tiveram o rugoso Olimpo. Dizei-me isto, Musas que tendes o palácio olimpio,

dês o começo e quem dentre eles primeiro nasceu

(HESIODO, 2011, p. 107-109).

\section{PRÓLOGO}

Por onde começar? Pelo começo absoluto, pelo rio Oceano, já que ele é, segundo o poeta cego em cujo canto a terra e o céu escampo e o que é e será e não é mais e longe e perto se abrem para mim, pai das coisas divinas e mortais, seu liquido princípio, fluxo e fim: pois ele corre em torno deste mundo e de todas as coisas que emergiram das águas em que, após breves percursos, mergulharão de novo um belo dia; e flui nos próprios núcleos e nos lados ocultos dessas coisas, nos quais faz redemunhos por cujos centros cavos tudo o que existe escoa sem cessar de volta àquelas águas de onde surge: não me refiro à água elementar que delas mana e nelas se confunde

\author{
com os elementos terra, fogo e ar \\ mas a águas que nunca são as mesmas: \\ outras e outras, sem identidade \\ além do fluxo, nelas só lampeja \\ a própria mutação, sem mais mutante: \\ um nada de onde tudo vem a ser. \\ escuridão de onde provém a luz, \\ tal Oceano é a mudança pura. \\ Mas eis que a poesia nos conduz, \\ feito um repuxo e a seu bel-prazer, \\ de volta ao princípio às criaturas \\ (CICERO, 2002, p. 11-12). \\ O poeta lírico
}

Não sei contar histórias. Minha prima,
Corina, que sabe fazê-lo, disse
ser esse defeito a causa ostensiva
do que, em falso tom de corriqueirice,
ela se deleita em qualificar
de "o óbvio malogro" das minhas lides
poéticas. Tive que concordar,
pois, por não sei que artes de berliques
e berloques, ela me criticava
com um argumento do próprio Filósofo
- para ela anacrônico e monótono -
em cuja obra-prima eu mergulhava
tempos atrás - e a fundo - e ela nada.
Eu morreria se tivesse um óbolo
(CICERO, 2012, p. 17).

A mistura heterogênea do poeta carioca, ao unir percepções da cosmologia da origem dos deuses e das coisas cantadas por Hesíodo às incertezas e anacronismos da contemporaneidade, aparece, ainda, na mescla de versos prosaicos - tão valorizados pelas poéticas modernista e pós-modernista - associados às construções em decassílabos e em heptassílabos. Vários relatos helênicos permeiam o presente da escrita poética que apresenta descontentamento na identificação do sujeito com a paisagem urbana. "Balanço", o poema que abre o livro Porventura, apresenta uma proposta de eclosão de tempos e espaços em prol de um acontecimento no qual o sujeito lírico experimenta o "agoral" (PORTAL, 2017), noção filosófica advinda dos estudos filosóficos de Antonio Cicero:

busca-se pensar o contemporâneo não enquanto uma simples atualização do passado, desde um olhar situado na atualidade, mas 
como um intervalo, uma cisão, uma fratura, no próprio atual, em que todos os múltiplos e heterogêneos tempos comparecem. Se o poema enquanto forma finita, limitada traria à tona uma ilimitação, é nele que se dá a possibilidade do infinito. É na ausência do atual que se realiza a experiência do próprio poema, pois a linguagem deste permite abrir a dimensão da potência de todos os dizeres, de todos os sentidos, da pura abertura, do agoral, do contemporâneo (PORTAL, 2017, p. 11).

Eis o poema ao qual nos referimos, no qual há a convergência de tempos e espaços em prol de sua realização agoral:

\section{Balanço}

A infância não foi uma manhã de sol: demorou vários séculos; e era pífia, em geral a companhia. Foi melhor, em parte, a adolescência, pela delícia do pressentimento da felicidade da malícia, na molícia, na poesia, no orgasmo; e pelos livros e amizades. Um dia, apaixonado, encarei a minha morte: e eis que ela não sustentou o olhar e se esvaiu. Desde então é a morte alheia que me abate. Tarde aprendi a gozar a juventude, e já me ronda a suspeita de que jamais serei plenamente adulto: antes de sê-lo, serei velho. Que ao menos os deuses façam felizes e maduros

Marcelo e um ou dois dos meus futuros versos (CICERO, 2012, p. 9).

Vista como uma "poética da negatividade" por Portal, a poesia de Antonio Cicero apresenta a "marca d'água do movimento", ou seja, está sempre em transitoriedade tempo-espacial, e é permeada pela mudança. Seus poemas possibilitam contatos do sujeito lírico a paisagens múltiplas, que se tornam desterritorializadas pela iminência de encontros entre espaços do presente com os do passado. Nessa possiblidade de enxergar, no presente, outros tempos, Antonio Cicero apresenta um poetar no qual o presente é registrado como uma parte não vivida do todo vivido, que, para Agamben (2009, p. 70), "a atenção dirigida a esse não-vivido é a vida do contemporâneo. E ser contemporâneo significa, nesse sentido, voltar a um presente em que jamais estivemos".

Findando, por ora, a leitura do poeta em ques- tão, cita-se o poema Nihil, de Porventura, que parece condessar essa negatividade da poética de Antonio Cicero e que deixa latente os deslocamentos e a impossibilidade em demarcar espaços fixos em sua palavra poética:

Nihil
nada sustenta no nada esta terra
nada este ser que sou eu
nada a beleza que o dia descerra
nada que a noite ascendeu
nada esse sol que ilumina enquanto erra
pelas estradas do breu
nada o poema que breve se encerra
e que do nada nasceu
(CICERO, 2012, p. 35).

\section{Referências}

AGAMBEN, Giorgio. O que é contemporâneo? E outros ensaios. Tradução de Vinícius Nicastro Honesko. Chapecó: Argos, 2009

ALVES, Ida; ANCHIETA, Marleide. (org.). Apresentação. In: Grafias da cidade na poesia contemporânea (Brasil - Portugal). Rio de Janeiro: Oficina Raquel, 2015. p. 7-9.

ALVES, Ida. Cruzamentos urbanos na poesia portuguesa recente. Via Atlântica, v. 15, p. 205-222, 2010. https:// doi.org/10.11606/va.voi15.50433.

ANDRADE, Mário. Poesias completas. Belo Horizonte: Itatiaia; São Paulo: Editora da Universidade de São Paulo, 1987.

CICERO, Antonio. A cidade e os livros. Rio de Janeiro Record, 2002.

CICERO, Antonio. A poesia e a crítica: ensaios. São Paulo: Companhia das Letras, 2017.

CICERO, Antonio. Finalidades sem fim: ensaios sobre poesia e arte. São Paulo: Companhia das Letras, 2005.

CICERO, Antonio. Guardar: poemas escolhidos. Rio de Janeiro: Record, 1996.

CICERO, Antonio. O mundo desde o fim. Rio de Janeiro: Francisco Alves, 1995

CICERO, Antonio. Porventura. Rio de Janeiro: Record, 2012.

COLLOT, Michel. La notion de paysage dans la critique thématique. In: Les enjeux du paysage. Bruxelles: Ousia, 1997.

COLLOT, Michel. La pensée-paysage. Versailles: Actes Sud, 2011.

COLLOT, Michel. O sujeito lírico fora de si. Tradução de Zênia de Faria e Patricia Souza Silva. Signótica, v. 25. p. 221-241, 2013. 
DELEUZE, Gilles; GUATTARI, Félix. O Anti-Édipo: capitalismo e esquizofrenia. Tradução de Luiz B. L. Orlandi. São Paulo: Editora 34, 2010.

ERTHAL, Aline. Ruy Belo e João Miguel Fernandes Jorge: cidades de volumes e arestas. In: ALVES, Ida; ANCHIETA, Marleide (org.). Grafias da cidade na poesia contemporânea (Brasil - Portugal). Rio de Janeiro: Oficina Raquel, 2015. p. 13-32.

HESíODO. Teogonia: a origem dos deuses. Tradução de Jaa Torrano. São Paulo: Iluminuras, 2011.

PEDROSA, Celia. Poesia, Crítica, Endereçamento. In: KIFFER, Ana; GARRAMUÑO, Florencia. Expansões contemporâneas: literatura e outras formas. Belo Horizonte: Editora UFMG, 2014. p. 69-90.

PEDROSA, Celia; KLINGER, Diana; WOLFF, Jorge; CÁMARA, Mario. (org.). Indicionário do contemporâneo. Belo Horizonte: Editora UFMG, 2018

PORTAL, Marcela. O mundo desde o fim: a poética negativa de Antonio Cicero. 2017. 209 f. Tese (Doutorado em Ciência da Literatura) - Universidade Federal do Rio de Janeiro, Rio de Janeiro, 2017.

\section{Paulo Alberto da Silva Sales}

Doutor em Estudos Literários pela Universidade Federal de Goiás (UFG), Goiânia, GO, Brasil. Possui estágio pós-doutoral em estudos literários, pela mesma instituição; docente da área de linguagens (lingua portuguesa, língua inglesa e literaturas) no Instituto Federal Goiano (IF Goiano), em Hidrolândia, GO, Brasil; professor no Programa de Pós-Graduação Stricto Sensu em Lingua, Literatura e Interculturalidade da Universidade Estadual de Goiás (UEG), GO, Brasil.

\section{Endereço para correspondência}

Paulo Alberto da Silva Sales

Rua T 37, 4029, Ed. João Paulo I, apto. 1002

Setor Bueno, 74230-022

Goiânia, GO, Brasil 